are both long term deals and could involve natural gas supplies of the order of 20,000 million cubic metres a year to Western Europe in 1980. The Siberian gas deals that have been discussed with US and Japanese companies in recent years (the Yakutsk and North Star deals) are larger and considerably more problematic. They involve tanker deliveries of liquefied natural gas out of a Pacific coast port and Murmansk, respectively, at a total rate of perhaps 50,000 million cubic metres a year over 25 years. The commercial and political obstacles to the eventual implementation of these deals are formidable. On March 31, however, a Soviet-US-Japanese agreement on joint exploration of the Yakutsk gas deposits was signed, with credits of $\$ 25$ million each being contributed by the Japanese and US consortia.

The fact that this preliminary agreement has been signed despite all the obstacles indicates the strength of both Soviet and Western interests in the development of Siberian energy supplies. The Western interest requires no explanation, but the Soviet interest is less immediately comprehensible. Why mortgage substantial future energy outputs to the West when energy supplies already form a bottleneck to your own economic growth?

The answer seems to be that Soviet energy production can grow much faster if Western technology is used, and the gains should be enough to repay Western suppliers (in gas) and still have something left over for domestic needs. Soviet technical deficiencies are beginning to show up in a number of key areas. The items which the Russians are unable to produce domestically in sufficient quality and/or quantity in the near future include wide-diameter $(1220$ and $1420 \mathrm{~mm})$ oil and gas pipeline, pipeline compressor equipment, machinery for deep drilling and secondary oil recovery, submersible pumps, offshore rigs and a wide range of coal mining equipment. It is likely that at least three-quarters of the $20,000 \mathrm{~km}$ of wide-diameter oil and gas pipeline laid in 1971-1975 was imported Western pipe. Costly pipe imports continue: in January and February about $\$ 500$ million worth of new orders were placed in Italy, Japan and France.

The picture of pervasive East-West interpendence which these projects evoke is misleading, however. Soviet natural gas deliveries to West Germany provide less than $15 \%$ of West German natural gas consumption. The corresponding figure for the USA in the early 1980 s in the event (now remote) of both the North Star and Yakutsk projects going ahead has been put at about $10 \%$.

On the Soviet side, the best assessment seems to be that the Russians will obtain an increase in energy supplies sufficient to support a respectable economic growth rate by a mixture of policies: shifting towards fuels less efficient than oil, incurring very large domestic development costs in Siberia, making some use of Western machinery and know-how and perhaps importing significant amounts of Middle Eastern oil. Neither Soviet nor Western energy-supply problems are sufficiently awful to ensure peace on earth and goodwill between Moscow and Washington.

\title{
BRITAIN
}

\section{Wave energy on}

Research in Britain on alternative sources of energy took a step forward last week. Allan Piper reports

THE first real move towards exploiting one of Britain's unconventional energy sources has come with last week's announcement that the Department of Energy (DEN) is to spend $£ 1.01 \mathrm{mil}-$ lions on a 2-year feasibility study of wave-power devices. If the programme is successful further research could lead to the development of such devices to provide up to half of Britain's electrical energy requirements early next century.

News of the venture coincided with the publication of the latest annual report on UK offshore oil and gas resources, which gives estimates that proven reserves of North Sea oil have increased by almost a third over the past year. Although the report revises the production forecast for 1980 slightly downwards, the new estimates are seen as offering the prospect of Britain attaining self-sufficiency in energy by the end of the decade, at the same time providing a stopgap until alternatives such as the wave-power scheme also come on stream.

The decision to press ahead with work on wave power is based on a National Engineering Laboratory report identifying it as a particularly promising energy resource. Early measurements indicate that the amount of wave energy available around British coasts varies between 40 and $70 \mathrm{~kW}$ per metre. The most abundant supplies are offered off north-western Scotland, but areas around the Cornish coast also show considerable potential. One advantage of wave power over other novel energy resources is that the wintertime peak of supply will coincide with maximum consumer demand.

The feasibility study is to assess the relative merits of four possible devices. Three of them, including the "Salter Duck", are British designs; the fourth is Japanese. All use different methods of converting wave energy to a usable form. Each one will be studied at a one-hundredth scale by teams of academic and industrial scientists. While looking principally at operational efficiencies and seaworthiness under varying conditions, they will also estimate approximate costs for any further research and development leading to seagoing trials.

A support programme will cover the collection and analysis of wave data, the long term effects of prolonged wave action on the structures, anchoring and mooring problems, likely environmental and navigational effects of large-scale installations, and possible modes of power generation and transmission.
The Central Electricity Generating Board has already started research into ways of integrating the supply into the national grid system.

Commenting on the decision to proceed with wave-power research, Dr Walter Marshall, Chief Scientist at the DEN, said that his department would retain control over the research teams through its Harwell-based Energy Technology Support Unit. The bulk of the $£ 1$ million will go towards the principal research programme; it will not be spread equally, but $\mathrm{Dr}$ Marshall gave no clues as to whether any of the devices had yet emerged as a clear favourite.

Stressing that the programme represented only an early exploratory phase of wave-power research, Dr Marshall said that further development depends on the findings of the next two years. If all goes well a $10 \mathrm{MW}$ prototype should be in the sea by 1986 , with a full-scale model operating by the 1990 s, but $\mathrm{Dr}$ Marshall declined to forecast a firm date for commercial power production, as past estimates of time-scales on such major projects have generally been "hopelessly optimistic". He did say, however, that commercial installations could be operating during the next century, and DEN figures show that a 600 mile chain of devices around north-western Scotland could eventually provide about half of Britain's present electrical energy requirements even on conservative estimates. Individual devices, each up 
to about $30 \mathrm{~m}$ across, will probably be linked together in $50-\mathrm{km}$ lengths.

International interest in the project has come from the International Energy Agency, which has asked Britain to take the lead in this area of research. The only other country so far seriously involved with wave power is Japan, but Dr Marshall estimated that the total British expenditureabout $£ 1.25$ millions including independent research funding-is around four times higher than in Japan. The figure must, however, be seen in perspective : the DEN could spend almost $£ 125$ million on nuclear energy this year alone. All the same, at this early stage, Dr Marshall said, any further spending on wave power is unlikely to contract the time-scale of research.

While the wave-power decision re- presents a significant Government step in a new energy direction, the DEN is also keeping its options open on other alternative sources of energy-solar, tidal, geothermal and wind. It is already engaged on two low-cost areas of research into a possible tidal barrage on the Severn Estuary between Wales and Somerset, and Dr Marshall has expressed a keen interest in solar power.

Even so, it seems clear that the DEN still regards the nuclear, coal, and oil and natural gas options as the mainstays of any future national energy strategy. Dr Marshall believes that the overall cost of wave-power installations could double those of nuclear generators providing comparable power, and his department remains committed to the fast breeder reactor. Additional hopes are pinned on the plan to boost coal production over the next ten years.

As for oil, the new production and reserve estimates are aimed at giving even more room for optimism than previously foreseen. Proven reserves are now placed at 1,350 million tons, compared to last year's, 1,060 million tons, and total reserves could be as high as 3,200 million tons. The production forecast, of 95 million to 115 million tons by 1980 , is down slightly on earlier estimates, because of difficulties and delays in commercial development programmes. DEN figures on energy trends, also published last week, meanwhile show that total UK energy consumption fell by $7.5 \%$ over the last year. Industrial consumption was down during the last quarter of the year by $17 \%$ on the corresponding quarter of 1974.
A statement last week from British Nuclear Fuels Ltd (BNFL), which has otherwise captured the public eye in recent months through its nuclear fuel reprocessing activity, disclosed that the UK Ministry of Defence has placed with it a contract for the production of supplies of tritium, the radioactive isotope of hydrogen (half life 12.3 years) which is a key material in the production of $\mathrm{H}$ bombs.

Construction is expected to start in June, following planning permission, of a facility at BNFL's Chapelcross Works, Dumfries, Scotland, where a plant originally built for plutonium production is now operated as a nuclear station supplying power to the national grid. The reactor there will irradiate with neutrons lithium metal which will then be treated in the new plant to separate out the tritium. The plant, which will employ fifty people, should be ready by 1980 .

Until now, the Radiochemicals Centre at Amersham has bought from France the tritium Britain uses for civilian purposes, while the Ministry of Defence has obtained its military supplies from the USA. The Ministry now says that a domestic source would be more convenient and would save dollars, but it is not clear whether the civilian imports will continue or whether commercial exploitation of the domestic production for export will be attempted.

BNFL itself has meanwhile faced mixed developments on the reprocessing front. The way ahead for the deal BNFL is sharing with Cogema of France to reprocess Japanese nuclear fuel recently became clearer with the resignation of electricity industry representatives from the Japanese negotiating team which has yet to commit itself following the broaden- ing of the deal to include Cogema.

On the home front, BNFL's Windscale site was recently the location for a gathering of several hundred people protesting against the use of nuclear power and, specifically, the fuel reprocessing carried out there. - If rabies should enter Britain, the threat would be to wildlife rather than the human population. Rabies, a report from the Office of Health Economics, urges surveillance to ensure that pets are not smuggled into the UK or allowed ashore from small boats. The danger results partly from the changing habits of an important vector of rabies, the fox, which as a suburban scavenger now comes into closer contact with domestic animals. For those at risk, meanwhile, the rabies vaccine produced in France and currently on trial in Britain could be both safer and less painful than those previously available.

The vaccine is prepared from the Pitman Moore strain of rabies virus, inactivated with $\beta$-propriolactone after being grown in cultures of human diploid cells. The vaccine produces high titres of rabies-neutralising antibodies, and shows promise for immunisation both before and after exposure to the disease. It represents a considerable advance on previous vaccines, produced from viruses grown in animal nervous tissue and duck embryos.

- The fluorocarbon arguments continue, and now the Department of the Environment (DOE) has published the results of a preliminary examination carried out with the assistance of Harwell, the Department of Health, and the Meteorological Office.

Based on studies ranging from the likely effects of fluorocarbons on stratospheric ozone to the health hazards posed by an increased influx of ultraviolet radiation, the findings suggest that the continued use of fluorocarbons at 1973 rates even for another century will ultimately destroy up to $8 \%$ of the Earth's stratospheric ozone, resulting in a $16 \%$ increase in radiation reaching the Earth's surface. This accords well with the conclusion of a similar World Meteorological Report published earlier this year.

Curbs on aerosols were not recommended, but there was a call for manufacturers and industry to step up the search for serious alternatives to fluorocarbons. The DOE report stresses that with so many uncertainties remaining the need for eventual regulations cannot be discounted, through it is hoped that ongoing research will clear up many of outstanding points within a couple of years.

A Minister in the Environment Department, Denis Howell, said (perhaps arguably) that the predicted increase in radiation levels was about the same as that incurred during a move from northern England to the south coast.

- The fluorocarbon report represents just one aspect of the work of DOE scientists, and along with environmental pollution, this department's research and development teams are also busily engaged with transport planning, building research and work on natural resources. From next August they will find themselves under a new Director General of Research when the present incumbent, $\mathrm{Mr}$ D. J. Lyons, steps down after five years in office to make way for Dr Martin Holdgate. Dr Holdgate, currently heading the NERC's Institute of Terrestrial Ecology, has experience leading research teams into South America. 